\title{
China's Search for Cultural and National Identity from the Nineteenth Century to the Present
}

\section{Werner Meissner}

\section{(2) OpenEdition \\ 12 Journals}

Electronic version

URL: http://journals.openedition.org/chinaperspectives/3103

DOI: 10.4000/chinaperspectives.3103

ISSN: 1996-4617

\section{Publisher}

Centre d'étude français sur la Chine contemporaine

\section{Printed version}

Date of publication: 1 November 2006

Number of pages: $41-54$

ISSN: 2070-3449

\section{Electronic reference}

Werner Meissner, « China's Search for Cultural and National Identity from the Nineteenth Century to the Present », China Perspectives [Online], 68 | november- december 2006, Online since 01 December 2009, connection on 28 October 2019. URL : http://journals.openedition.org/chinaperspectives/3103 ; DOI : 10.4000/chinaperspectives.3103

This text was automatically generated on 28 October 2019

(c) All rights reserved 


\title{
China's Search for Cultural and National Identity from the Nineteenth Century to the Present
}

\author{
Werner Meissner
}

1 This article describes and analyses crucial elements of cultural and national identitybuilding in China from the nineteenth century to the present, in particular the response of China's intellectual elite to Western influences. In this context, I will first touch briefly on similar phenomena in other regions, such as Russia, the Arabic world, and Germany. By doing so, I hope to show that what happened in China was, and is, not an isolated case but typical of modernising societies.

2 Secondly, after a brief description of the term "Chinese cultural identity", the unfolding of the identity crisis in China following its continuous defeats by Western powers in the nineteenth century will be described. The third part of the article outlines the attempts of China's intellectual elite to develop a new cultural and national identity after the decline of Chinese Marxism-Leninism. The article deals with the main currents of identity-building and the perception of the West by discussing the rising importance of Confucianism, the role of history and language, and the renaissance of Western thought.

3 Finally, the focus will shift to the emergence of different types of Chinese nationalism as a response to Western imperialism: Anti-Manchuism at the end of the nineteenth century, the nationalism of Sun Yat-sen and his followers, the state-nationalism of the Chinese communists until 1979, and the discourse on nationalism since the 1980s.

Discourses on cultural and national identity

4 Identity has become a paradigm for the individual and for groups and nations in their search for safe ground in disturbed times. The term is defined in its most general form by Erikson: "the term identity expresses ... a mutual relation in that it connotes both a persistent sameness within oneself (selfsameness) and a persistent sharing of some kind of essential character with others." ${ }^{1}$ Thus, individual identities can only be established within group identities. Each person has multiple collective identities, 
which can be defined through gender, kinship, space or territory (local and regional identity), class, education, occupation, institution, religion, ethnicity, race, culture and, finally, nationality and supra-nationality. ${ }^{2}$

5 Individual and national identities are not static, but are changing continuously. Each individual, group and nation always tries to redefine his/her/its identity when it is challenged, endangered or broken. This is understood as an identity crisis. The search for and redefinition of a new identity is a process of adaptation, in which a new equilibrium is sought between traditional elements and new challenges. The identity crisis is solved as soon as a new equilibrium, however temporary, is achieved.

Discourses on cultural and national identity have been part of nation-building in Western Europe since the eighteenth century. They can also be found in Russia and Germany in the nineteenth century. Outside of Europe, they started dominating intellectual debates in Asia as soon as it was threatened by Western powers and Western ideas, but also in the Arabic world. It was a discourse on modernity, which at first began in the European states, and then, as a response to Western imperialism, continued until today in those parts of the world that were or still are under the influence of Western powers.

7 I would like to mention three examples that show similar patterns to those found in China. The first is Russia, where there was a discourse between "Slavophiles" and "Westernisers" from the 1840s to the 1870s (and again today). The Slavophiles wanted Russia's future development to be based on values and institutions derived from the country's early history instead of from the West. They took their ideas mainly from German philosophy, especially German Idealism (Herder, Schelling, Fichte and Hegel). The two main founders of the Slavophile movement, Khomyakov (1804-1860) and Aksakov (1817-1860), thought that Russia should not use Western Europe as a model for its modernisation, but should follow a course determined by its own values and history. Western Europe, especially Britain and France, was viewed as morally bankrupt and Western liberalism and capitalism as outgrowths of a decaying society. The Russian people, by contrast, should adhere to the Russian Orthodox faith and unite in a "Christian community" under authoritarian rule. Spiritual values should replace Western rationalism, materialism, individualism, capitalism and liberal democracy. The Slavophiles were opposed by the Westernisers, a group that developed simultaneously with them and which insisted that Russia should imitate the Western pattern of modernisation and introduce constitutional government into the tsarist autocracy.

A second example is Germany. At the beginning of the nineteenth century, the German "Bildungselite" developed the foundations of a German national identity that was separate from the western part of Europe. Many German intellectuals rejected the ideas of the French Revolution and, further stimulated by its excesses and the subsequent Napoleonic Wars, developed an anti-Western mindset. Moreover, the emerging political liberalism was weakened in Germany following the failure of the 1848 revolution. As a corollary, political modernisation and industrialisation did not progress in a synchronic way. In the second half of the nineteenth century, the traditional political and socio-cultural structures were not transformed during the rapid industrialisation. To some extent, industrialisation was stuck onto the existing state and society. ${ }^{3}$ The Prussian landed aristocrats, the German army officer corps, and the state bureaucracy clearly tried to dodge any attempts at political reform. The political and social development, in particular the formation of a liberal, parliamentarian constitutional 
state, therefore lagged behind the technical and economic developments. The majority of the cultural and political elite did not regard itself as part of the "West"; on the contrary, its aim was to create a strong and authoritarian nation-state, based on an ethnic German national and cultural identity, in opposition to Western European ideas of liberalism and parliamentarianism. ${ }^{4}$

German Idealism, Romanticism, and historicism had always stressed the particular individuality of German intellectual life in the face of the cultures of the Western European nations. Together with the idea of the special role of German culture, these elements were merged into a defensive ideology against the ideas of Western European and American parliamentarianism and political liberalism in the field of politics; the dominating role of empiricism, pragmatism and positivism in the field of philosophy; and against capitalism in the field of economics.

Finally, in the Arab world, there was (and still is) the struggle between clerical conservatives-or even fundamentalists - and modernists. Since the seventh century, some Muslims currents have believed in the superiority of their culture over all other cultures. But with the rise of the West, Islam lost its sense of superiority, and the crisis in modern Islam has led to the emergence of a "defence-culture" (the consequences of which can still be felt today). The ideas of Egyptian theologians Muhammad Abduh (1849-1905) and Hasan al-Banna (1906-1949) here exhibit a pattern comparable with the Russian and German example. They wanted to modernise Arab societies based on Islam and the Koran. They too, did not accept the concept of Western culture, but they did accept the technical-scientific aspects of Western modernity, a pattern that Bassam Tibi once described as a "dream of half modernity." In other words, to face the challenge, it was necessary only to adopt and develop modern technology, but not its cultural aspects (the "project of cultural modernity" by Habermas). ${ }^{5}$

11 Generalisations in history are always dangerous. The deeper one looks into each single case, the more differences will be found. But despite many differences, the abovementioned patterns can be found in nearly all modernising societies in the past, not only in Russia, Germany and the Arabic world, but also in China. In all of these cases, intellectuals and politicians claimed the superiority of their allegedly "spiritual culture" (the Christian faith, Islam, the German spirit and, in China, Song-Ming NeoConfucianism) over the so-called rationalist and "material civilisation" of the West, whereas their opponents favoured a political philosophy that was based on a utilitarian-rational worldview with the idea of a democratic representative government.

Nations that suffered from Western oppression, occupation, and/or expropriation tended to move to and fro between extreme ideological orientations: either fending off Western modernity or selectively integrating parts of it into their own, frequently overdrawn, traditional worldviews, or even dismissing their own culture in part or in whole and replacing it with radical ideologies such as Marxism-Leninism. This is also true for China. Since the middle of the nineteenth century, large parts of China's political and intellectual elite have followed similar patterns to find an answer to the "Western threat", whether it was based on a Confucian or, later, on a Marxist-Leninist tradition.

In search of cultural identity

Although Chinese intellectuals differ on how to respond to the Western challenge, more or less all who have dealt with Chinese history in one way or another agree on certain 
aspects, which they regard as parts of Chinese cultural and national identity (perhaps with the exception of the early Marxists). Among these main aspects are:

- the long history of China-at least four to five thousand years;

- the identity of the Han people as the descendents of the legendary Yellow Emperor;

- the continuity of the idea of a Chinese Empire running through all dynastic changes and foreign rule;

- the uniqueness of the Chinese language;

- the tradition of religion and philosophy (or Chinese thought);

- Chinese literature, poetry, painting, ceramics, music, etc.;

- the impressive number of inventions in areas such as medicine, weaponry, shipbuilding, porcelain, etc, which in many cases were unsurpassed until the Renaissance; and

- despite many regional varieties, a common everyday culture, including Chinese food.

At the beginning, this self-perception was not so much an ethnic one - belonging to the Han race-as a cultural one, belonging to the Chinese "Kulturkreis" (culture area), a Chinese culturalism. Chinese culture was so attractive that it led to a long-lasting predominance over the nations and tribes that surrounded it. This predominance, and the feeling of being superior to other nations, was an additional aspect of the identity that had developed over the centuries.

The loss of China's traditional hegemony in Asia, when tribute states such as Annam, Siam, Burma, Laos and Korea became Western or Japanese colonies, and the so-called "unequal treaties," by which the Western powers forced their conditions upon China, were felt to be a deep humiliation (xiuru羞辱). Later this humiliation was even "instilled into the pupil's mind"6 to arouse nationalistic feelings. This feeling of humiliation became part of China's national identity.

China's defeat in the Opium War in 1840 was the beginning of a perennial identity crisis among intellectuals that lasts until today. The crisis caused by the West was different from the previous crises of the Chinese Empire, such as the occupation by the Mongols and later the Manchus, and could not be met with the same response - the assimilation and acculturation of the "barbarians," who finally became Chinese. Although the Manchu emperors never questioned the cultural identity of the Chinese educated elite-on the contrary, they promoted it in many ways because they needed it to rule China-the West challenged the essence of Chinese culture and the fundamentals of the elite's self-perception.

China's search for a response to the Western threat unfolded roughly within five periods.

The first period

The first period lasted from the middle of the nineteenth century until 1895. During this time, the classic paradigm was "Chinese learning as essence (or substance), and Western learning for application (or as) function" (Zhongxue weiti, xixue weiyong 中學為 體, 西學為用). This slogan meant a selective adoption of Western civilisation, namely its technological and scientific aspects for technical application only, whereas "Chinese learning," the traditional Chinese culture, was to remain the essence of individual life, society and state. The Western threat was reduced to the problem that China would only have to "learn from the superiority of the foreigners in order to rein in their superiority” (Zhang Zhidong, 1837-1909). 
19 As a result, the political elite started building a modern arms industry and laying the foundations of the industrialisation of the empire by establishing arsenals, mines, railways, etc. The aims of these modernisation policies, which ran from 1861 to 1894 under the slogans, “Movement for self-strengthening” (ziqiang yundong 自強運動) and “ Yangwu movement 洋務運動” (in which yangwu stands for foreign affairs), were:

- the protection of the threatened territorial integrity of the Chinese Empire;

- the protection of the predominant role of Chinese culture against the allegedly subversive influence of Western ideas; and

- the conservation of the existing Confucian system of rule in the interests of the political and social elites.

This conservative or partial modernisation failed, as we know. The factories that were established did not function properly, and in 1894 China lost the next war, this time with Japan, which had started out on the road not only of economic, but also of political, reform through the introduction of a constitutional monarchy.

The second period

21 During the second period (1895-1911), a different pattern emerged. Intellectuals, such as Kang Youwei (1858-1927), Liang Qichao (1873-1929), and Tan Sitong (1865-1898), recognised that it was not sufficient merely to adopt Western technology, but that political reform was also necessary. However, for the leading reformer, Kang, a radical break with tradition was not conceivable. Instead, he looked to the Confucian classics to find an answer to the Western challenge. In his article "Confucius as Reformer," (Kongzi gaizhikao 孔子改製考) published in 1897, he presented the idea that the great master had himself been an adherent of institutional change. Under the slogan, “changing the institutions based on the teachings of the old times" (tuogu gaizhi 托古改 製), Kang attempted to win the necessary ideological legitimisation for political change by returning to a reformed Confucianism. In his memoranda to the emperor, who appointed him as his adviser in 1898, he recommended a series of reforms, which aimed to bring about three important changes:

- the abolition of the traditional Sino-centrist worldview and the acknowledgement of foreign powers as states enjoying equal rights;

- the equality of Chinese and Western learning (Kang demanded the introduction of educational institutions following a Western pattern and the founding of a university in Beijing, later called Beida); and

- the transformation of the empire into a constitutional monarchy.

The "Hundred Days Reforms" in 1898 foundered, partly because of the hastiness with which they were implemented and partly because of the resistance of conservative court circles. Nevertheless, it is evident that Kang Youwei and his reformers clearly recognised one thing: the adoption of Western technology alone was not sufficient to rescue the existing political system or even China. For the first time, Chinese intellectuals acknowledged the equality of Chinese and Western learning.

The third period

The third period covers the first republic from 1911 to 1949. In my view, this period is the most important. Neither before nor since have Chinese intellectuals discussed so thoroughly and comprehensively Western ideas and Chinese culture. As in a prism, one can find all political groups from the right to the left and their respective attempts to find an answer to China's pressing problems. Four main groups emerged. 

Zhidong and trenchant critic of Westernisation, and Zhang Junmai (Carsun Chang, 1887-1969), an adherent of Neo-Confucianism, a strongly idealistic and mystical form of Confucianism that goes back to Zhu Xi (1130-1200) and Wang Yangming (1472-1528). Gu accused the radical intellectuals of betraying China and destroying the oldest civilisation in the world. To him, European civilisation was a "material monster" that was going to destroy Chinese civilisation like a "Trojan horse" from within. ${ }^{7}$ On the other side, China's civilisation was superior, because it was "spiritual" (jingshen), and should help the West to free itself from the ideology of "materialism." Zhang also believed in the superiority of China's "spiritual culture" (jingshen wenhua 精神文化) over the "material culture" (wuzhi wenhua 物質文化) of the West, especially as far as the mechanistic natural sciences were concerned. In this context, he already distinguished between Germany and the West and favoured a selective adoption of science, Western idealist philosophy, in particular German Idealism, and the German model of social and economic development. ${ }^{8}$

Nationalists around Sun Yat-sen (1866-1925) and his party, the Guomindang. Sun tried to synthesise the Confucian tradition with Western political liberalism in his main work, Sanminzhuyi 三民主義 (Three People's Principles). He too was convinced that China's culture was superior, but was ready to introduce Western democratic institutions in China as part of a national government.

Liberal thinkers such as Hu Shi (1891-1962), who had been influenced by American pragmatism (John Dewey). In contrast to the Neo-Confucians, they were convinced that only the "scientification" of Chinese thought in all areas-i.e., not just in technology, but also in the social sciences and humanities-and the "total Westernisation" (quanpan xihua 全盤西化) of Chinese civilisation, connected with the adoption of political liberalism and a controlled capitalism, would bring about the re-establishment of China's greatness. ${ }^{9} \mathrm{Hu}$ Shi, under the influence of John Dewey, was also the first to recommend a federal political structure for China based on "self governing provinces" (liansheng zizhi 聯省自治), rather than a centralised political system. ${ }^{10}$ Union as a model for China. They aimed to destroy Chinese "feudal" culture, especially Confucianism (dadao kongjiao 打倒孔教) and establish a new socialist identity based on Marxism-Leninism.

These groups clashed in numerous controversies, starting with the "May Fourth Movement" in 1919; the controversy over "East West culture" and "Science and Metaphysics" in the early 1920s; and over "Westernisation" in the 1930s. In these discourses, China's cultural tradition became an essential part of national identity. The educated elite realised that it was necessary to create a national language to protect China's culture, to develop national education, and, if possible, even to prove that science, through which the West had demonstrated its superiority, had its roots in China as well. Only by a thorough overhaul of China's culture and institutions, was it possible to cope with the Western threat. Linguists, educators, historians, archaeologists, artists, and scientists: they all became the architects of China's new cultural and national identity. Here I will touch briefly on the sciences only. Other areas, such as sociology, philosophy, religion, language and literature show similar patterns regarding their role in the search for cultural identity.

Sciences

China Perspectives, 68 | november- december 2006 

明: compass, paper, gunpowder and printing) as examples of the high level of Chinese civilisation in many fields. How did Chinese intellectuals get along with the fact that the Western sciences were superior? Conservatives simply declared that all Western sciences were of Chinese origin (Xi xue zhong yuan 西學中原) and that one should adopt only those aspects that could already be found in China. By pointing to the Chinese origin of Western sciences, superiority over the West was maintained. At the same time, this attitude facilitated the adoption of modern sciences and technology and made it easier to acknowledge their temporary superiority, simply because they, allegedly, originally came from China. However, during this process of adoption, the Chinese scientific tradition was classified by Western categories of natural and social sciences and partly reinterpreted. The setting up of modern disciplines, especially in the 1920s and 1930s, was paralleled by intensive research on Chinese precedents and by an attempt to link up Western sciences with Chinese tradition. By doing so, intellectuals hoped to develop a genuine identity as Chinese scientists.

This attitude was common to conservatives, liberals and Marxists. Hu Shi, for example, who was perhaps the most "Westernised" literary scholar and who had initiated the "literary revolution", looked for the roots of science in China. Together with the reformer Liang Qichao, he believed that the scholars of the early Qing dynasty, such as Gu Yanwu (1613-1683), Huang Zongxi (1610-1695), and Dai Zhen (1724-1777), best represented the scientific tradition. In their view, these scholars had used empirical methods in their research on history, philology and phonetics that could easily match Western sciences. A second example was Ding Wenjiang (1887-1937), the well-known geologist who had studied in London and had been Director-General of Greater Shanghai in the1920s. Ding regarded the famous geographer Xu Xiake (1586-1641) and his research as a precedent of modern Western geography. The general view was that to revive China's great tradition in science and technology, it was only necessary to link up the empirical tradition of the Qing period with modern science. Whether $\mathrm{Hu}$, Liang and Ding were right in their assumption does not matter here. I think they exaggerated a bit, but the most important aspect here was that they tried to bring Chinese and Western knowledge together and to present them as one part of the world's common knowledge and wisdom: we, the Chinese, take part in the global emergence of a scientific world community, bringing our own achievements. ${ }^{11}$

\section{Westernisation}

The discourse on science, but also on liberalism, the European enlightenment, and the future model of the Chinese state, was embedded in the general discourse on Westernisation (xihua 西化). The dispute about the supposed necessity to Westernise or about the similarly asserted necessity to take one's own path independently of the West became the red thread of all discussions. These were not limited to the 1920s, but continued in the 1930s (and returned in the 1980s).

From 1933 to 1935, there took place among Chinese sociologists an up to now largely disregarded controversy on "Total Westernisation" (quanpanxihua). Among the adherents of Westernisation were Chen Xujing (1903-?), a professor of sociology and political science at Lingnan University in Canton, as well as other scholars, such as $\mathrm{Lu}$ 
Guanwei, Feng Enrong and Lü Xiehai, also at Lingnan University. The main arguments of the "Westernisers" in the 1930s were:

- the uniformity of culture and the interdependence of all of its aspects (politics, philosophy, the economy and social institutions);

- the superiority of Western culture and the idea that the old Chinese culture was not suited to the modern world;

- Westernisation as a general, world-embracing trend, with the idea that if China wanted to have an influential place in the world, then it must Westernise itself; and

- that certain parts of Chinese culture were already Westernised, but only externally (i.e., the system of government, the traffic system, industry) and that this Westernisation was not only insufficient but also dangerous, because it concentrated only on the material achievements of the West and neglected the spiritual foundations of Western society that were the basis of these achievements. ${ }^{12}$

Among the opponents of Westernisation were the Neo-Confucian scholars Zhang Junmai and Liang Shuming (1893-1988), to name only two. To Zhang, it was necessary to connect the Chinese (special) path (dao 道) with Western instruments ( $q i$ 器), to preserve the national characteristics (guoqing 國情), and to shape Chinese culture on a Chinese foundation (Zhongguo benwenhua 中國本文化).

Chinese scholars also made a very clear distinction between the West and Germany. Germany was not perceived as belonging to the West. Many opponents of Westernisation, especially the modern Neo-Confucian camp, regarded Germany-its culture, its policy of state-guided modernisation since Bismarck, and its education system - as a model for China's rebirth. In their search for ideological allies against the West, the Confucians of the 1920s and 1930s looked above all to Germany (whereas the Chinese communists looked to Russia, and the liberals to America). They hoped to revive the Confucian and spiritual tradition by integrating German metaphysics, primarily the philosophy of Kant, Hegel and Fichte. ${ }^{13}$ Chinese and German (mostly conservative) intellectuals even envisaged some kind of cultural co-operation in addition to the already very close military and economic co-operation of the time. German idealistic philosophy and Chinese philosophy should unite against Western civilisation. Translation projects (German philosophical works into Chinese and Chinese philosophical works into German) were started with exactly this purpose in mind, among them, of course, Fichte's famous "Reden an die deutsche Nation". The Chinese translation was published on the occasion of Japan's occupation of Manchuria. ${ }^{14}$ More than 1,300 German-language books had been translated into Chinese by the beginning of the Second World War, the majority of them works on culture and philosophy. ${ }^{15}$ This discourse slowed down in the late 1930s, due to two major events: the Chinese-Japanese War and the looming victory of the Chinese communists in the civil war after 1945.

The fourth period

The fourth period, from 1949 to 1978, was characterised by the attempt to create a cultural and national identity based on Marxism-Leninism. After the establishment of the new Chinese central state, Marxism-Leninism, in combination with the thought of Mao Zedong, became the new state-orthodoxy. The new political class legitimised its claim to absolute power by Marxism-Leninist doctrine. This "New Philosophy" (xin zhexue 新哲學) provided an official identity for the individual and the nation, and the followers of other intellectual currents, such as Western liberalism, positivism, 
pragmatism, idealism, religion and traditional Chinese thought, were frequently forced out of their positions and persecuted. On might say that Marxism-Leninism served as

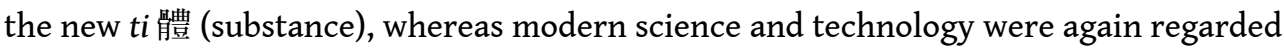
as yong 用 (function).

The period between 1949 and 1978 can be regarded as a period of the far-reaching dismissal of European and Chinese culture at the same time. The Party tried to eradicate Western influence with the exception of the natural sciences and Marxism. It also tried to root out so-called Chinese "feudal" culture. However, the Party obviously failed in its attempts to impose a cultural and national identity based on communist ideology upon the Chinese people.

The fifth period

Following the Third Plenum of the Eleventh Central Committee in 1978, at which Deng Xiaoping's reform policy was initiated, the fifth and, so far the latest, period began. It was characterised by three important developments:

- the renaissance of Confucianism;

- the renaissance of Western thought; and

- the emergence of various nationalist movements in the Chinese-speaking area.

The renaissance of Confucianism

In most post-Leninist countries, we can observe a renaissance of traditionalist thought that is frequently linked to nationalistic and ethnic or even racist tendencies. Strong tendencies towards re-traditionalisation can be observed in non-communist countries too-in particular in the Islamic world, where anti-Western movements are on the advance-but also in the United States, so speaking of a global phenomenon is justified.

The renaissance of Confucianism started around 1986 under the guidance of the Communist Party, when the then member of the state council, $\mathrm{Gu} \mathrm{Mu}$, became the chairman of the newly founded Confucian society. ${ }^{16}$ Furthermore, between 1986 and 1989, more then 300 articles were published on modern Neo-Confucianism alone, represented by Feng Youlan (Feng Yu-lan), Tang Junyi (T'ang Chün-yi), Mou Zongsan (Mou Tsung-san), and Du Weiming ( $\mathrm{Tu}$ Wei-ming). Since then, numerous studies on Confucianism and Taoism have been published. A further indication of this revival were three international symposiums on Confucianism at the beginning of October 1989. More than 300 scientists and adherents of Confucianism came together, some even from Taiwan. This happened only three months after the crackdown on the prodemocracy movement. Obviously, the adherents of Confucianism were not offended by the suppression of the student movement.

The speeches delivered by high cadres Jiang Zemin, $\mathrm{Gu} \mathrm{Mu}$ and others at the symposiums revealed that the political leadership clearly functionalised traditional concepts to broaden its dwindling legitimisation after June $4{ }^{\text {th }} \cdot{ }^{17}$ Confucianism became part of a traditionalist cultural nationalism and an instrument to counter Western political influence. One year later, at an international congress in November 1990 in Beijing, Zhu Xi, the founder of Neo-Confucianism in the twelfth century and once the ideological archenemy of the Chinese communists, was finally rehabilitated.

41 There is no doubt that the renaissance of Confucian thought helps to solve the problems of cultural identity that necessarily arise during rapid modernisation. However, similar to the intellectual situation in the 1920s and 1930s, modern NeoConfucianism also shows a tendency against Western political liberalism. For the 
Chinese Communist Party, the revival of Confucianism in the 1990s served a dual purpose. Confucianism implies order, obedience to one's superior, devotion to the state, and the protection of the family. It puts the interests of the group above the interests of the individual, and thus helps to promote social harmony and stability. Its authoritarian aspects can be used to build a "socialist spiritual civilisation" and to promote social harmony. At the same time, Confucianism can help to provide people with some sort of national identity and to defend Chinese culture against the so-called threat of Westernisation. ${ }^{18} \mathrm{~A}$ "National Confucianism" can serve as a bulwark against the ideological impact of the West following rapid modernisation. ${ }^{19}$ The international symposium in Xi'an, also in November 1990, on China's modernisation and Chinese traditional culture, obviously not only re-established Confucianism as a means to check the social and political effects of modernisation, but also as a part of a national ideology. ${ }^{20}$

The rewriting of history

Parallel to the renaissance of Confucianism began the rewriting of Chinese history that started slowly in the 1980s and accelerated after 1989. One example is the re-evaluation of former national heroes such as Zeng Guofan (1811-1872), the governor-general and first moderniser; Li Hongzhang (1823-1901), the second great moderniser; Lin Zexu (1785-1850), who drove the British out of Canton; Guo Songtao (1818-1890), the first ambassador to Britain; and even General Yue Fei (1103-1142), a national hero of the Southern Song Dynasty. I will focus here on Zeng only. In 1993, a three-volume historical novel about Zeng was published and reprinted 19 times within two years, with more than two million copies sold. An encyclopaedia of Zeng Guofan was published in 2000, and the number of articles and books about him is rising. ${ }^{21}$

Throughout modern Chinese history, Zeng has been regarded as a model of national salvation and nation building. Liang Qichao, Yuan Shikai and Chiang Kai-shek praised him as a national hero who had helped to preserve the Chinese "race" and state. Only Sun Yat-sen was critical of Zeng, because he had supported the Manchus, but even Mao Zedong admired him before Marxist historians labelled him as a "traitor of the Han" (hanjian 漢奸). In their view, Zeng was a "lackey" because he served the Manchus. Moreover, his modernisation policy allegedly only served Western interests. ${ }^{22}$

There are several reasons why Zeng is now held in high esteem. Firstly, he was a great moderniser and reformer, not a revolutionary. Secondly, his modernisation policy was based on Confucianism. Thirdly, he defeated the Taipings (once regarded as the precursors of the Chinese communist revolution), who were Christians (a Western religion), and had attacked Confucianism. Finally, he defeated a political movement that was based on the peasantry. Understandably, to many historians, Zeng safeguarded Chinese culture and "Chineseness," which were under threat from two sides: Christianity from the outside and peasant uprisings, which were from the inside, but which had allegedly been hijacked by outside forces. Zeng thus becomes a symbol of resistance against Westernisation (from the outside) and revolution (from the inside).

One can speak of a paradigmatic shift in the perception of national history that has had deep repercussions with respect to national identity and domestic politics. As a result, Marxist-Leninist historiography seems to be in retreat. The rehabilitation of Zeng puts into question the legitimacy of the Chinese Communist Party as a representative of the peasantry and the proletariat. Peasant movements are not regarded as progressive forces anymore, and the period since 1911 is seen as an aberration of China's real 
history. Cultural identity means turning to the roots of China's culture, and dismissing the West and social uprisings. The self-image of the Chinese Communist Party is here at stake.

Language

The rewriting of history after 1979 cannot be separated from another aspect of Chinese cultural identity: language. Cultural nationalists around the renowned International Chinese Character Research Association and its main organ, "Chinese Character Culture” (Hanzi wenhua 漢字文化, CCC), believe that the old characters (fantizi 繁體字) are an essential part of Chinese culture and identity. Chinese linguists, such as Shen Xiaolong, Xu Jialu, Ji Jin, and Xiao Tianzhu, even claim that ideographs are superior to phonetic scripts and that Chinese is not only the clearest and most concise language in the world, but also the easiest to learn. They also claim that Chinese grammar is the closest to mathematics and may be the best international language. Subsequently, the "theory of the superiority of Chinese" has replaced the previous "theory of backward characters." There is no space here to go into more detail, and I again refer readers to Guo Yingjie's study. ${ }^{23}$ However, there are two more aspects that underline the arguments put forward by the linguists, and to which I would like to add.

First, Taiwan and Hong Kong have always used fantizi. They have been the two regions of the Chinese-speaking world that have had the fastest modernisation in Asia (apart from Japan). The old characters may not have promoted modernisation, but they have definitely not been an obstacle to it. They have also not been an obstacle to alphabetisation and character learning, as the literacy rate is still higher in Taiwan and Hong Kong than it is on the Chinese mainland. Therefore, the Party's policy of language reform was probably based on wrong assumptions. Secondly, neither Taiwan nor Hong Kong, nor overseas Chinese communities, will stop using traditional Chinese characters in the future. Communication and cultural identity building have now become more complicated due to two different character systems. Thirdly, to build a genuine cultural and national identity, there is no way of getting around the old characters when dealing with historical documents and reading the classics. Finally, and in my personal view, Chinese traditional characters are very beautiful and of high aesthetic value-something that is missing in many of the simplified characters. It would be a loss to China's culture and to the aesthetic education of the people if the traditional characters disappeared from textbooks and from daily life.

The renaissance of Western thought

The renaissance of Western thought is the second important development. Following the opening up of the country, Chinese intellectuals started translating numerous philosophical books and articles on Western philosophy into Chinese and published an even greater number of their own studies on this topic. There now exists for the first time statistical material about Chinese publications on Western philosophy over a period of 11 years (1987-1997). ${ }^{24}$

49 The number of titles during that period is approximately 10,000 (today the figure will be much higher). They include more than four hundred and fifty translations of books, approximately seven hundred translations of articles, and approximately six hundred and fifty books and eight thousand articles by Chinese authors. The titles can be further divided into three hundred and fifty general introductions and textbooks, nearly seven hundred studies of comparative philosophy (China and the West), three hundred and fifty studies of aesthetics, more than three hundred and twenty of ethics, and around 
four hundred and fifty of the philosophy of science and technology, to name only the largest groups. The figures look even more impressive if one bears in mind that only titles on Western Marxism have been included (i.e., the Frankfurt School), but no titles on Chinese Marxism or Marxism-Leninism.

A brief look at the titles provides evidence that Chinese scholars have a strong interest in European continental philosophy, especially German-language philosophy, but not as much in Anglo-American philosophy. German philosophy accounts for a large share, with about one-third of the titles. This is due in part to the fact that after 1949, German Idealism, in particular Hegel's philosophy, was able to survive in the shadow of Marxism-Leninism. Still on top between 1987 and 1997 is Hegel with more than four hundred and sixty titles, followed by Kant (437), Heidegger (178), Nietzsche (174), Sartre (154), Popper (128), Aristotle (114), Husserl (95), Wittgenstein (93), Plato (87), Hume (84), Schopenhauer (82), Rousseau (79), Habermas (68), and Gadamer (59). Among the few Anglo-American thinkers are Rorty (41), Locke (39), Quine (30), Dewey (27), Rawls (26), Hobbes (14), James (12), Mill (6), and Hayek (4). (All figures refer to the period 1987 to 1997.)

One major field of interest is comparative studies. There are 650 studies alone of the differences between Western and Chinese philosophy. Some focus on the general differences between the two philosophies and cultures. Others compare Chinese and Western philosophers, for example, Kong Zi and Meng Zi with Protagoras, Socrates, Plato, Aristotle, and Kant; Zhuang Zi with Sartre; Xun Zi with Hegel; Lu Jiuyuan with Berkeley; Zhang Zai with Spinoza; Wang Fuzhi and Yan Yu with Kant; Yan Yuan with William James; Hu Shi with Gadamer; Zhuang Zi with Nietzsche; Dai Zhen with Descartes. Several studies investigate the differences between Heidegger and Zhuang Zi.

The question of the depths of these comparative studies cannot be answered here, but the figures and titles show a rising tendency among Chinese scholars to investigate the differences between Chinese and Western philosophy and to develop their own standpoint and cultural identity by contrasting Chinese tradition with Western thought..$^{25}$

National identity

During national crises, such as the Chinese-Japanese War in the 1930s and 1940s, language and literature, science, pedagogy, history, philosophy and art have been subsumed into nationalist ideology and movements and the discourse on national identity. The overarching ideology of all of these aspects is nationalism and national identity. Hence, I would like to make a few comments on Chinese nationalism here.

Since the 1990s, the amount of literature on Chinese nationalism has grown rapidly. I mention here only the most important ones: studies by Unger, Dikoetter, Pye, Schubert, and Hays Gries, and by our Chinese colleagues, Zhao Suisheng, Zheng Yongnian, and Guo Yingjie, to name only a few. However, having run through the literature regarding the definition of nationalism, I am still inclined to follow Kohn's general distinction between a Western, more liberal kind of nationalism (also called liberal or civic nationalism) and a Central and Eastern nationalism (also called ethnic and cultural nationalism), to which German nationalism belonged until the Second World War. Whereas Western nationalism comprised, at least in its origins, the ideas of individual liberty and rational cosmopolitanism that were current in the eighteenth century, the emerging nationalism in Asia tended towards a different development. Dependent 
upon, and opposed to, influences from without, this new nationalism was characterised by an inferiority complex that was often compensated for by over-emphasis and overconfidence. As Kohn rightly observed:

"All rising nationalism was influenced by the West ... yet this very dependence on the West often wounded the pride of the native educated class as soon as it began to develop its own nationalism, and ended in an opposition to the "alien" example and its liberal and rational outlook." ${ }^{26}$

One major reason for this was the cultural hubris, arrogance and, frequently, racism that had become an inherent part of Western nationalism and imperialism in the nineteenth and twentieth centuries. Therefore, the Asian nationalist movements developed in opposition to the West and contained strong cultural, ethnic, and even racist-but few liberal-elements. Nationalism mainly meant liberation from Western oppression, not from autocratic rule in one's own country. National leaders, such as Sun Yat-sen in China, Nehru in India, and Sokarno in Indonesia, developed their concepts of national identity out of a struggle against Western and Japanese imperialism.

The first type of Chinese nationalism was ethnic and even racist. Originally, it was a movement to get rid of the Manchus and went back to the seventeenth century, when Ming loyalists such as Gu Yenwu (1613-1682), Huang Zongxi (1610-1695), and Wang Fuzhi (1619-1692) continued to fight against the newly established Qing dynasty (1644-1911). Anti-Manchuism, together with anti-imperialism, was also expressed in the writings of Zhang Binglin (1868-1996), who regarded China's penetration by the West as the biggest threat. To prevent the decline of Chinese culture, the "yellow race" should unite against the white invaders. ${ }^{27}$

The second nationalist concept, minzuzhuyi 民族主義, was developed by Sun Yat-sen. Minzuzhuyi is usually translated as "nationalism." However, this translation is very vague. The characters minzu clearly indicate a meaning of "race" and "nation". Min means "people", and $z u$ can be translated as "clan". In connection with zhong (zhongzu 种族), it means “race”. Hanzu 漢族 is translated as “Han nationality". In Sun's view, there are several elements that contribute to nation building: above all, the blood relationship (xuetong 血統), followed by the conditions of life (shenghuo 生活), language (yuyan 語言), and religion (zongjiao 宗教). According to Sun, the blood relationship is the most important power that constitutes the Chinese nation. ${ }^{28}$ His nationalism (minzuzhuyi) belongs to the category of so-called ethnic/cultural nationalism and is comparable to the early nationalism of Germany (Volkstumsidee) ${ }^{29}$ and some Eastern European countries. Sun also stated that Chinese culture was superior to Western civilisation, but, at the same time, he strongly emphasised the necessity of adopting Western science and political institutions. He tried to combine his idea of nationalism with the basic concepts of Western liberalism, representative democracy, and the separation of powers, and proposed five democratically elected political institutions (three Western and two Chinese) - the five Yuan - thus offering for the first time a synthesis between Confucian tradition and Western liberal democratic values. ${ }^{30}$

The nationalism of the Guomindang was very different from the concept of "patriotism" (a term borrowed from the Soviet Union, and, in Chinese, aiguozhuyi 愛國 主義) represented by the Chinese communists, which Mao Zedong mentioned for the first time in his famous speech on "The Place of the Chinese Communist Party in the National War" in 1938. 
59 classic Chinese culture as an important element of Chinese identity. On the contrary, the nation was based on classes (class nation), ${ }^{31}$ the peasantry, the proletariat and the petty and national bourgeoisie. In the 1980s, after the so-called Cultural Revolution, when large parts of China's cultural heritage were destroyed, the Chinese Communist Party's approach to culture slowly changed. Step by step, the Party began to reinstate Chinese culture as an element of Chinese nationalism, together with ethnic aspects and Confucian ideology.

Patriotism became especially important in the aftermath of June $4^{\text {th }}$. The embattled Party searched for a new legitimisation and developed a two-pronged approach. First, the Party insisted that patriotism and socialism could not be separated. ${ }^{32}$ According to Jiang Zemin: "in China today, patriotism and socialism are unified in essence." Patriotism is regarded as the premise behind China's socialism, and socialism is the inevitable conclusion of genuine patriotism. Second, the Party took the lead in reevaluating China's history and making use of traditional concepts, such as cultural nationalism, ${ }^{33}$ Confucianism, and even racial nationalism, to promote social stability and to strengthen its legitimacy. The original patriotism, which had been based on class structure, was discarded, and the debate on cultural nationalism explored the concept of "Chinese modernity" as an alternative to Western modernity. Events, such as the Taiwan crisis (1995-1996) and strained relations with the United States and Japan, played a catalytic role in this debate, as they helped to divert attention from the real issue of political modernisation to ethnic nationalist emotions.

61 nationalism. A brief look at Chinese history reveals that racist thinking has never been foreign to Chinese politics. In the past, the traditional term "barbarian" could easily be loaded with racial connotations, as Wang Fuzhi did with reference to the Manchus. The list of racial stereotypes used by Chinese scholars since the nineteenth century is long. ${ }^{34}$ Reformers from Yan Fu to Liang Qichao regarded racial identity as a key element in China's struggle for racial survival (baozhong 保种) and rebirth. The "yellow race" was engaged in a merciless struggle with the "white race." Chiang Kaishek (Jiang Jieshi) spoke of the "various stocks" in China not just as one nation, but also as "one race." 35 Darwinism, combined with racism and a belief in China's cultural superiority, became the main building blocks of Chinese national identity before 1949. However, one should always take into consideration that this terminology was strongly influenced by European ideas. Racism in Europe was in vogue at the beginning of the twentieth century, and Chinese intellectuals were by no means alone in applying racial terms and theories. They took them from the West. ${ }^{36}$

Racial nationalism seems to have become more and more important as an element to help establish collective identity, especially after 1989. Sautman has collected statements by high-ranking Chinese communist cadres that obviously reveal racial thinking. ${ }^{37}$ Official documents emphasise the common ancestry of the Han and minorities. Han and Tibetans are regarded as parts of a common race, and the early historical Tibetan and Yellow River cultures are regarded as identical. Tibetans allegedly belong to the Chinese nation through this blood relationship. ${ }^{38}$ These and other examples indicate that racial nationalism seems to be on the rise and plays an important role in the discourse on national identity. 
63 and even racial thinking, one cannot speak of one Chinese national identity or one Chinese nationalism. Instead, as Gladney has argued ${ }^{39}$, one can observe the fragmentation of Chinese identity, even among the Han majority, and the emergence of various regional identities and national movements in the Chinese-speaking area. The Communist Party is struggling to keep all of these, in some cases centrifugal, forces under control by utilising traditional cultural, ethnic, and racial elements under the umbrella of "Socialism with Chinese characteristics."

In addition to the already existing state nationalism or patriotism of the Party, one can identify the following "nationalisms."

- Popular autonomous nationalism, which emerged in the 1990s and surfaced in various autonomous demonstrations (against the United States and Japan [1999, 2005]) and publications. ${ }^{40}$ The government seems to be indifferent to such nationalism, although it could become dangerous (as in 1919) if the Party does not take the right measures against Japan or the United States to placate the movement. It is not possible to say in which political direction this nationalism might head in times of national crisis-whether more democratic and anti-government or more conservative and anti-foreign. The second option seems to be more likely.

- Tibetan and Uighur nationalisms, which became stronger in the 1990s. Both are ethnic and religious movements. ${ }^{41}$ The first may even contain democratic elements, due to the personality of the Dalai Lama and the exiled Tibetan elite. The second is clearly ethnic and religious, either demanding autonomous rights guaranteed under the Constitution or even independence.

- Taiwanese nationalism. The rehabilitation of Taiwanese culture has favoured the cultural identity of the Taiwanese and has supported the rise of Taiwanese nationalism in the 1990s. Though the ethnic aspect is very strong, the synthesis of ethnic and democratic concepts has created a civic and liberal type of nationalism in a Chinese-speaking area for the first time, which could be a model for the Chinese mainland too. ${ }^{42}$

- Democratic nationalism, which is clearly underdeveloped on the mainland. There are a few scholars who favour democratic nationalism and the introduction of a democratic regime in China, such as Wu Guoguang, Ding Xueliang and Zheng Yongnian, but none of them teaches on the mainland.

In view of these different types of nationalism, it is perhaps better to speak of "nationalist movements in the Chinese-speaking area" rather than of "Chinese nationalism," and of a still troubled Chinese national identity.

Outlook

Since the 1980s, intellectuals, as well as the people, have had the possibility of recovering their cultural past. This is one of the most positive aspects of this period. For the first time since 1949, Chinese people on the mainland have had the chance to develop their own identity by immersing themselves in their own culture and simultaneously adapting to modernity.

What is the political dimension of these new developments? Are they indicators of a desirable democratisation of Chinese society in all areas? As desirable as this would be, skepticism is yet called for, as the following observations show.

1. One can observe the build-up of two main positions, both of which might become the dominating political movements in the future and both of which to a certain extent refer to traditions in Chinese thought. There is not only an extremely disputed and officially

China Perspectives, 68 | november- december 2006 
combated tendency towards Westernisation, but, as already seen in the 1920s and 1930s, there has emerged at the same time a counter-tendency in the form of a revival of conservative ideologies.

2. The pro-democracy movement of the 1980 s and its theoretical foundations revealed strong deficiencies regarding socio-political preconditions, as far as the path to a more democratic and pluralist state in future was concerned. In the following years the partial modernisation conducted by the government favoured negative developments, such as corruption and the abuse of power, and no independent political institutions have been created for their control. At the same time, the building up of a counter-ideology, of a bulwark against the political liberalism and pluralism of the West, continued.

3. The renaissance of traditional Chinese thought, especially of Neo-Confucianism, seems to support a rising ethnic and cultural nationalism, and not necessary political liberalism and democracy. (In this, there is some similarity to the partial modernisation of Germany as a "delayed nation" in the second part of the nineteenth and first part of the twentieth centuries and its anti-Western and anti-liberal ideologies.)

4. However, the quantity of translations and Chinese studies on Western thought since the 1980s represents a phenomenal feat by Chinese intellectuals, and it is no exaggeration to speak of the beginning of a new chapter in the intellectual history of China and its dealing with Western ideas. This is, together with the "recovering" of the Chinese past, a very positive aspect. Although Marxism-Leninism and Maoism still prevail on the surface, the foundations of other systems of thought have been laid down and have started to exert their long-lasting influence. The pluralist nature of the intellectual discourse is no longer stifled by a closed system of thought as it was in the past. Chinese scholars have started recovering their philosophical tradition, and, in comparing it with the West, they are building new cultural identities in their search for modernity. Moreover, there is reason to hope that the continuous study of Western philosophy in China, and of Chinese philosophy in the West, will lead to a common understanding that basic modes of thinking can be found in both cultures, and that these can be used to establish the foundations for a better intellectual discourse in the future.

5. The attempts to apply some modes of Western thought do not necessarily imply a rapprochement between China and the West, in which the fundamental political values of Western democracy and parliamentarianism will eventually be adopted in something like a "democracy with Chinese characteristics," as has happened in Taiwan. On the contrary, one cannot rule out that the traditional anti-Western ideology in China will become an amalgam consisting of Confucian elements, combined with set pieces of Party ideology, anti-Western, non-liberal philosophy, and based on an ethnic, or even, racist identity. Under the slogans of "patriotism" and "Chineseness," such a nationalistic ideology could be used by the leadership to present itself as the core of the "Chinese nation," which, in addition to the Han people, would automatically include the official minorities, the Taiwanese, Hong Kongers, and overseas Chinese.

68 The rising nationalist rhetoric and the attempts to create a collective Chinese identity among all of these different groups is a threat to their individual ethnic and cultural identities. It is this official policy that forces the minorities to rediscover and redefine their own identities, and which arouses national feeling among them. A solution to the clash between conflicting cultural and national identities in China could lie in the development of a multi-ethnic nationalism that is based on the principles of political liberalism. However, this would mean the adoption of the second "half of modernity." 


\section{NOTES}

1. Erikson, Erik H. (1959) Identity and the Life Cycle. New York, Norton, pp. 27-28.

2. Smith, Anthony D. (1991) National Identity. Reno, University of Nevada Press, 3ff; Dean, Kathryn (ed.) (1997) Politics and the End of Identity. Brookfield (United States), Ashgate, pp. 1-46. For an attempt to clarify the concept with regards to China, refer to Dittmer, Lowell \& Kim, Samuel S. (eds.) (1993), China's Quest for National Identity. Ithaca, Cornell University Press.

3. Ralph Dahrendorf (1965), Gesellschaft und Demokratie in Deutschland (Society and Democracy in Germany). Munich, Deutscher Taschenbuch Verlag, 55 and 59.

4. On the problems addressed here, compare above all the works by Dahrendorf R., op.cit.. Faulenbach, Bernd: Ideologie des deutschen Weges. Die deutsche Geschichte in der Historiographie zwischen Kaiserreich und Nationalsozialismus. München 1980. Vierhaus, Rudolf: Die Ideologie des deutschen Weges der politischen und sozialen Entwicklung. In: Die Krise des Liberalismus zwischen den Weltkriegen. Edited by Thadden, Rudolf von. Göttingen 1978, pp. 96-114. Mosse, George L.: The Crisis of German Ideology. Intellectual Origins of the Third Reich. New York 1964. Stromberg, Roland N.: Redemption by War. The Intellectuals and 1914. Lawrence 1981. From the French side also the essay by Groh, D.: Le "Sonderweg" de l'histoire allemande entre 1848 et 1945: mythe ou réalité? In: Annales 38, 1166-87. A short but very good summary of the problems can also be found in Löwenthal, Richard: Gesellschaftswandel und Kulturkrise. Zukunftsprobleme der westlichen Demokratien. Frankfurt a. M. 1979, pp. 268-70.

5. Jürgen Habermas: Der philosophische Diskurs der Moderne, Frankfurt $1986^{3}$. The "project of cultural modernity" is based on the universality of the values of the Enlightenment and the French revolution, subjective reason as precondition of any scientific activity, reflective dealing with tradition, emancipation from traditional bonds and social/political powers. Compare Habermas, 10f, and Bassam Tibi, Islamischer Fundamentalismus, moderne Wissenschaft und Technologie, Frankfurt 1992, p. 20.

6. Compare Frank Dikoetter, "Culture, 'Race' and Nation," in: Journal of International Affairs, Vol. 49/2, Winter 1996, p. 602, footnote 25.

7. One of his works has been translated into German: Ku Hung-ming (Gu Hongming), Chinas Verteidigung gegen westliche Ideen. Kritische Aufsätze, Eugen Diedrichs Verlag, Jena 1911.

8. Cf. Werner Meissner (1994), China zwischen nationalem 'Sonderweg', und universaler Modernisierung - Zur Rezeption westlichen Denkens in China, München: Wilhelm Fink Verlag, pp. 147-171. Still the best biography on Zhang Junmai is Roger Bailey Jeans, Democracy and Socialism in Republican China: the politics of Zhang Junmai (Carsun Chang) 1906-1941, Rowma and Littlefield 1997. The only German presentation is Hung Mao-hsiung (1980): Carsun Chang (1887-1969). Seine Vorstellungen vom Sozialismus in China. Inaugural Dissertation. München.. Short presentations also in Tan, Chester C. (1972), Chinese Political Thought in the 20th Century. Newton Abbot, pp. 253-266.

9. On Hu Shi, see the still unmatched work by Grieder, Jerome (1970) Hu Shih and the Chinese Renaissance, Cambridge MA, Harvard University Press. 
10. Hu Shi zuopin, Taipei 1986, pp. 75-82. Refer also to Grieder (1970), p. 195).

11. Cf. Meissner (1994), 50ff, $184 \mathrm{ff}$.

12. A short overview of the controversy is provided by Kolonko, Petra: "The Challenged National Identity. When Chinese Wanted to Become Westerners. The "Debate on Total Westernization," in: China 1934-35. In: East Asian Civilizations, No. 2, 1983, pp. 168-174. The Chinese contributions are printed in: Lü Xiehai (Editor): Quanpanxihua yanlunji (Collected essays on total Westernisation), Canton 1934; Feng Enrong (Editor): Quanpanxihua yanlunxüji (Further collected essays on total Westernisation), Canton 1935, and Mo Faying (Editor): Quanpanxihua yanlun sanji (Third collection of essays on total Westernisation), Canton 1936. (References from Kolonko, op. cit., p. 168.) See also Gransow, Bettina: Geschichte der chinesischen Soziologie (A history of Chinese sociology), Frankfurt/ New York 1992, S. pp. 101-114.

13. Compare Meissner (1994), p. 171.

14. "Reden an die deutsche Nation" (Speeches to the German Nation), published in 1808 on the occasion of Napoleon's occupation of Germany, became the "bible" of German nationalism. Translated by Zhang Junmai: Feixide deyizhiguominrenjiang, 1932, Reprint Taipei $1970 .^{4}$

15. Cf. Lee Kuo-chi (1975), Kultureinfluß Deutschlands auf China im 20. Jahrhundert, in: Tradition und Neubeginn. Internationale Forschungen zur deutschen Geschichte im 20. Jahrhundert. Edited by Hütterer, J. et al. (1975), Köln, pp. 215-220, cf. 219.

16. A good survey of the revival of Confucianism can be found in Lee Minghui: "Das Konfuzianismusfieber im heutigen China," in: Der Konfuzianismus, Ursprünge Entwicklungen - Perspektiven, eds. Ralf Moritz und Lee Minghui, Leipzig 1998. Also Jing Wang, High Culture Fever. Politics, Aesthetics, and Ideology in Deng's China, Berkeley 1996, p. $64 \mathrm{ff}$.

17. Cf. Renmin Ribao (October 8th and 9th 1989), Guangming Ribao (October 8th and 9th 1989), and XNA, (October 8th and 9th 1989).

18. So Chen Zhengfu and He Zhiqing, explicitly, in their book Kongzi, Ruxue yu Zhongguo xiandaihua (Confucius, Confucianism and Chinese Modernisation) (Fujian: Xinhua 1992), page 238ff: "Xiandai xinrujia yu Zhongguo xiandaihua."

19. The term "National Confucianism" was first used by Jean-Philippe Béja in his article: "The Rise of National-Confuciansm," China Perspectives (Nov. /Dec. 1995), pp. 6-11.

20. Cf. Brunhild Staiger "Chinas Modernisierung und die traditionelle Kultur," in: China aktuell (January 1991), p. 31-39.

21. The following paragraph is mainly based on the excellent study by Guo Yingjie, Cultural Nationalism in Contemporary China, London 2004.

22. For details compare the chapter on Zeng in Guo, $49 \mathrm{pp}$.

23. For details of the debate, see Chapter 5 in Guo, 91 pp.

24. Cf. Werner Meissner (2001), Western Philosophy in China, 1993-1997. A Bibliography. Euro-Sinica, Vol. 11, Berlin, Bern, Bruxelles, Frankfurt, New York, Oxford, Wien: Peter Lang Verlag 2001, and Die Rezeption der westlichen Philosophie in der VR China, 1987-1992. Eine Bibliographie, in co-operation with Liu Weijian, Münster, 1996.

25. A brief look into the Yearbook of Chinese Philosophy (Zhongguo zhexuenianjian) published since 1998 shows that the occupation with Western philosophy has intensified. Compare Zhongguo zhexue nianjian, 1998 - 2006, Zhongguo shehui kexueyuan zhexueyanjiu suobian, Beijing. 
26. Kohn, Hans (1945) The Idea of Nationalism. Macmillan, New York. Kohn's distinction has been the focus of much criticism. However, the German, the Russian and the Chinese cases, as well as the developments in the former Yugoslavia, seem to justify his definition. Refer to Hutchinson, John \& Smith, Anthony (eds.) (1994) Nationalism. Oxford \& New York, Oxford University Press, $160 \mathrm{ff}$.

27. On Zhang Binglin, compare Laitinen, K. (1990), Chinese Nationalism in the late Qing Dynasty - Zhang Binglin as an Anti-Manchu Propagandist, London.

28. Dr. Sun Yat-sen, San Min Chu I: The Three Principles of the People, trans. Frank W. Price, ed. L. T. Chen (Shanghai, China: China Committee, Institute of Pacific Relations, 1927.

29. Cf. Gottfried Karl Kindermann, who made this point already very early in his book: Konfuzianismus, Sunyatsenismus und chinesischer Kommunismus, Freiburg 1963

30. Legislative Yuan, Executive Yuan and Judiciary Yuan, taken from the Western system, combined with two institutions from the Chinese administration: the control Yuan and the examination Yuan.

31. Cf. Gunter Schubert (2002), Chinas Kampf um die Nation. Hamburg, 116ff, $133 \mathrm{ff}$.

32. Qiushi (1990), vol. 9: 8-9, quoted after Pye, Lucian (1996) “How China's Nationalism was Shanghaied," in: Unger, Jonathan Chinese Nationalism. New York, M. E. Sharpe, pp. 86-112, p. 106.

33. Cf. Schubert (2002), p.192 ff. on cultural nationalism in the $1990 \mathrm{~s}$.

34. Frank Dikoetter, "Group definition and the idea of race in modern China (1793-1949)," in Ethnic and Racial Studies, Vol. 13, no. 3, July 1990: 420 ff.

35. Chiang Kai-shek (1947), China's Destiny, New York: 39.

36. Cf. Frank Dikoetter (1992), The Discourse on Race in Modern China, London.

37. Barry Sautmann, "Racial Nationalism and Chinese External Behaviour," in: World Affairs, Fall 1997, Vol. 160, Issue 2: $78 \mathrm{ff}$.

38. Haemoglobin studies have been conducted to prove the supposed racial kinship of the Chinese and the minorities. For details, see Sautmann, op. cit.

39. Dru C. Gladney, Dislocating China: Muslims, Minorities and Other Subaltern Subjects, Chicago, The University of Chicago Press, 2004.

40. The best known were China can say no (Zhongguo keyi shuo bu), published in 1996, and Behind the scenes of the Demonization of China (Yaomohua Zhongguo de beiho), also in 1996. For more details see Jean-Pierre Cabestan: "The many facets of Chinese nationalism," in: China Perspectives, No. 59, May-June 2005, pp. 26-40.

41. On the emergence of Hui and Uighur nationalism in China, compare Gladney, op. cit., also Werner Meissner, Der internationale Terrorismus aus ostasiatischer Sicht -

Chinas Reaktion auf den 11. September und die Veraenderungen seiner geopolitischen Lage, in: Sicherheit und Verteidigung nach dem 11. September 2001, Strategische Kultur Europas, vol 1, ed. by August Pradetto, Frankfurt 2004, pp. 157-174

42. On Taiwanese nationalism, compare in detail Gunter Schubert, Chinas Kampf um die Nation, op. cit., 277ff., and Jean-Pierre Cabestan, "Specificities and limits of Taiwanese nationalism," in: China Perspectives, No. 62, November-December 2005, $32 \mathrm{ff}$. 


\section{ABSTRACTS}

The paper describes and analyzes crucial elements of cultural and national identity-building in China from the $19^{\text {th }}$ century to the present: the unfolding of the identity crisis following its repeated defeats by Western powers in the $19^{\text {th }}$ century and the attempts of China's intellectual elite to develop a new cultural and national identity. The paper also deals with the main currents of identity-building and the perception of the West since the 1980s by discussing the rising importance of Confucianism, the role of history and language, and the renaissance of Western thought after the decline of Marxism-Leninism. Finally, the focus will be on the emergence of different types of Chinese nationalism since the $19^{\text {th }}$ century and the recent discourse on nationalism. 